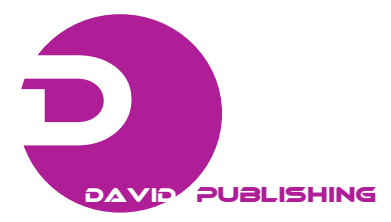

\title{
The Socio-economic Characteristics of Albanian Returned Migrants
}

\author{
Valentina Sinaj, Elena Tomori (Myftaraj), Fatmir Memaj \\ University of Tirana, Tirana, Albania \\ Dajana Berisha \\ Ministry of Labour, Tirana, Albania
}

\begin{abstract}
This paper attempts to unfold certain socio-economic characteristics of Albanian undocumented or "irregular" migrants returning from EU member states. The idea emerged from an IOM research followed by a study conducted two years ago (2007-2008) on this particular Albanian migratory development. The paper aims to contribute to the early chapters of a future potential empirical research, thus stimulating theoretical discourses towards defining the socio-economic profile of Albanian returned migrants. The research among Albanian undocumented migrants returned from Greece, the UK, etc., indicates that many of the above migrants were found to be recidivists, crossing borders frequently and undocumented. Greece being the main destination and simultaneously (deporting) country, leads to the assumption that it is the main destination country for undocumented migrants. The number of Albanian returnees from Greece reaches its peak, notably in April and September, with the start of seasonal works. The number of returned Albanian minors invoke problematics that demand for appropriate attention and assistance during the procedures of readmission (return, handover by the returning authorities, readmission by Albanian authorities etc.). With regard to causes of undocumented migration, one might identify a slight tendency among undocumented young migrants, to qualify poverty as the main reason rather than lack of working opportunities as Albanian middle age migrants would argue.
\end{abstract}

Keywords: returned migration, data collection, socio-economic profile

\section{Introduction}

Return migration has been considered a recent phenomenon in Albania. Piracha and Vadean (2009) as such the impact of this phenomenon in the labor market and social development within the country may as well be considered under researched.

An IOM (2008) empiric findings supports the main assumptions that the authors of this paper wish to

Valentina Sinaj, Ph.D., Faculty of Economy, University of Tirana.

Elena Tomori (Myftaraj), Ph.D., Faculty of Economy, University of Tirana.

Fatmir Memaj, Ph.D., Professor, Faculty of Economy, University of Tirana.

Dajana Berisha, MA., Social Affairs and Equal Opportunities, Ministry of Labour.

Correspondence to this article should be addressed to Valentina Sinaj (co Fatmir Memaj), P.O. Box. 1506, Tirana Albania.

E-mail:sinajv@yahoo.com. 
elaborate. The IOM research on its own has made use of primary data collected through TIMS $^{1}$ and a survey conducted recently in Albania.

The survey acknowledges a questionnaire conducted among Albanian undocumented migrants returned to the borders of Albania from Greece and deported from other EU member states.

The information gathered through the questionnaire at four Police Border Control includes data on the education level, duration of stay, migrants skills as well as reasons for migrating and returning.

The main area of inquiry and standpoint of these data and information collected and used for the purpose of this paper indicates that irregular migration continues to prevail and function as a phenomenon in Albania, in spite of a casual decline in recent years.

The awareness of authors brings readers closer to the perception that the return of undocumented migrants currently is carried out in the framework of readmission agreements, for those countries where a readmission agreement is in force, or under other bilateral/multilateral cooperation agreements.

In the understanding of Kruse (2006) the readmission agreement between Albania a country in transition and the Commission in 2004 anticipated the setting up of a $€ 30$ million framework preparatory action for return covering transportation and integrated return programmes to run during 2005 and 2006.

Nevertheless return migration can be a complex topic, entailing many dimensions. Thus this paper suggests for a multi-disciplinary approach when considering the designation of the socio-economic profile of involuntary returned or deported Albanian undocumented migrants. At theoretical level the topic requires various other researches considering that existing literature, projects and theoretical discussions such as King (2005), King and Vullnetari (2003), De Bruycker (2005), Castaldo (2007), Black, Jones, Pantiru, Wheeler, Skeldon, and Vathi (2007) etc., conducted mostly address Albanian international migration as an escape strategy from poverty. The policy-orientation dimension fits quite well with the topic, considering that this paper addresses new developments arising from the endorsement of the Readmission Agreement of Albania with EU member states in 2004 and the institutional capacities of Albania to handle properly the effects of readmission (Kruse, 2006).

Indeed one might consider a benefit to this paper the integration and harmonisation of the human rights aspect of deportation process as part of all immigration policy agendas across European Union, part of who Albania aspires to be.

Albanian undocumented or "unauthorised” migrants (Apostolatou, 2006) are being deported in groups of various sizes and by different means. In cases of migrants caught in distances not very significant, the Greek authorities deport them to Albania's borders in small groups and via four by four jeeps, or even escorted in police vans (Mema, 2008). While migrants caught within Greek soil, are collected and deport towards Albanian borders on buses overflowing with people. This is a picture given by interviews and one may as well agree with Mema (ibid) when arguing about the problematic strategy of deportation and treatment implemented at borders between Albania and Greece during the deportation process of Albanian undocumented migrants.

\footnotetext{
1 Total Information Management System (TIMS), is a computerised system designed in 2004 for supporting the border police officers. TIMS (Sistemi i Administrimit Total të Informacionit) is assisting the immigration police officers to prepare reports and statistcs accordint to: entrance of Albanian citizens in Albania; entrance of foreign citizens in Albania; departure of Albanian citizens; departure of foreign citizens; entrance and departure of vehicles (according to plate numbers and types); deportees and suspicious nationals; information regarding vizas issued BCP; information regarding paid fees for foreigners at the PBC, wanted and arrest orders; documents declared lost, stolen, unvalid and blocked at borders; stolen and lost vehichles.
} 
The assumptions that this paper tries to amplify are that no decline of the flux of returnees has been observed in the last two years. With regard to the connection between migration and human rights, human trafficking continues to be observed among female migrants crossing borders irregularly (Memaj, ibid).

\section{Methodological Approach}

With regard to methodological approach the research relied on face-to-face interviews to explore the journey of undocumented migrants as well as on analyses of the data gathered at Police Border Control Offices with regard to return migrants. In support of the assumptions of this paper, authors make use of the primary data collected through TIMS including information qualified as such from questions and answers deposited from returnees at the Police Border Control. Cases including certain information considered as confidential by police officers have been excluded from research questioners and surveys.

The realization of the research for the purpose of this paper faced some complexities. The information accumulated by Police Border Control Officers was not permanently accurate and easily accessed for all research cases and in the context of information received by migrants it reflected weak configuration confusion of interviewees. Hence as Opie (1992) suggests that it is important to be aware of signs of contradiction while researching and interviewing. Such contradiction is located more in a philosophical reading of self and identity. Acknowledgement of contradiction challenges the notion of rationality, affirming instead a much more unstable, decentred notion of self and calls for the representation of this self within the written text.

This contradiction while researching and conducting interviews made it completely impossible for the acquiring of the information in a quantity form. Considering this limitation, the authors concluded to select and to generalize some of the acquired information. Additional indispensably research for return migration of undocumented Albanian migrants would be necessary for the purpose of defining a comprehensive socio-economic profile of returnees alongside with their impact on the origin country (research that could be completed during a second stage of work hence initiated by this paper).

\section{Exiting From Albania Holding Regular Visas}

In many cases, Albanian migrants claim to relocate in countries like Switzerland, Italy, Germany, the UK, Greece, the USA, Belgium using regular visas (particularly in the main PBC).

Reasons for leaving Albania consist for the most part of interviews "working purposes" in professions like construction, plumber, joiner, and singer unoccupied, etc., nevertheless other reasons complete the entire migration journey as well. Family unification, marriage with citizens of the above countries etc., have been qualified as reasons for undocumented migration.

\section{Deportation and Its Reasons According to Interviewer's Perceptions}

It is argued that return migration is a part of life cycle (Piracha \& Vadean, 2009), part of a migration journey encompassing involuntary return, refusal of asylum cases leading to return and simply deportation of undocumented migrants.

In the case of Albanian returned migrants main reasons for their return consist of expiration of their residence permit in the case when they hold regular entry visas. Nonetheless, other reasons were considered as sufficiently important to be listed for the purpose of deportation process to happen and for further legal and 
theoretical elaborations.

Penal prosecution for dissimilar penal actions such as clobber, transport of monetary values, transport of cannabis etc.

Returned in more than one case not only from Greece, but from other countries as well.

Prohibition to enter in different countries, for a period often for up to 10 years.

Use of forged documents as Kosovan citizens.

Deported with the false excuse that the deportees were under request from another country.

\section{Unaccompanied Minors}

Walking to Greece illegally (patterns of Albanian undocumented migrants crossing the Greek boder). Crossing the border in groups (particular guiders claim to know the way).

Unskilled migrants mostly unoccupied, with occasional employment, carrying out jobs such as paintings, construction etc...

Considering Greece as the overpass towards Western Europe, the USA often through a paid intermediary.

Attempt to unite the family since the Embassy did not grant a visa.

Convicted that have suffered part of their conviction and who return?????

Short period without documents (up to 10 years)????

Family unification already residing in Greece.

Families with numerous members and with low economic means.

\section{Data Analysis}

Considering that, Albanian deportees comprise $94.8 \%$ of the total returnees; their impact on the process seizes an important role. The structure of TIMS allows authors to access different data enabling the elaboration of socio-economic analysis with regard to the returnees. Based on the data collected from April 2007-2008 the research highlights the following:

The average number of daily returnees includes 193.5 persons.

The majority of migrants return at the PBC with Greece and in particular through Kapshtica PBC.

The number of migrants varies through months (The flux of returnees' decreases in January followed by an increase in May and a decrease during the period of June-August. The second peak of migrants' return is marked in September with a decrease for October-December.) The available data notes an association of returns and deportation of Albanian undocumented migrants with seasons when Greek farmers needs more labor force.

To follow this hypothetic argument the comparison of the number of returnees from different PBC with Greece supports the argument over the association of returned migration with seasonal works as the main returns take place in the Kapshtica PBC. The other hypothetic explanation behind this existing reality is the fact that Kapshtica PBC is the most used border passage (due to labor market in North Greece) by the majority of the undocumented migrants coming from North, Northeast and East of Albania.

The number of migrants returned to Rinas PBC fluctuates constantly and does not present a regular model of behavior throughout an entire year. However, the number of returnees for the first four months of 2008 is lower when compared with the level of returnees for the same period during 2007.

The following data helps the authors to approach and initiate few assumptions: 
Returnees to the Kapshtica PBC amounts for more than $50 \%$ of the total number of returned migrants.

Greece is considered the number one deportation country of undocumented Albanian migrants with a total deportation of 87,255 persons.

The Greek authorities handling the return of Albanian undocumented migrants are divided in five PBC of Greece and the Albanian authorities handling the readmission of national citizens are located at two PBC respectively (PBC of Rinas Airport and PBC of Goricë).

The return of undocumented Albanian migrants consists mainly on 90.4\% returned to PBC with Greece, 5.6\% of migrants returned to PBC from other countries such as $2.4 \%$ returned to PBC from FYROM, $1.1 \%$ returned to PBC from Montenegro and finally $0.5 \%$ returned from Kosovo.

The ranking of the PBC with Greece according to the number of the returnees is as follows: Kapështica 55.2\%, Kakavia 23.8\%, Qafë Bot 17.5\%, Tre urat (Three bridges) 2.2\%, and Saranda 1.3\% (see Figure 1 and Figure 2).

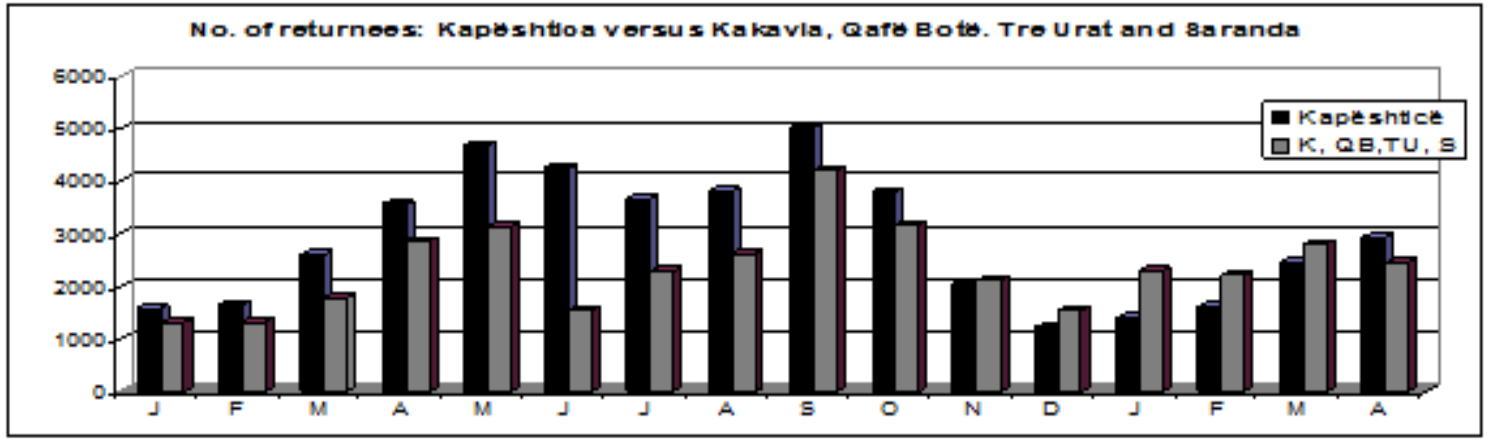

Figure 1. Number of returnees. Source: IOM, Tirana.

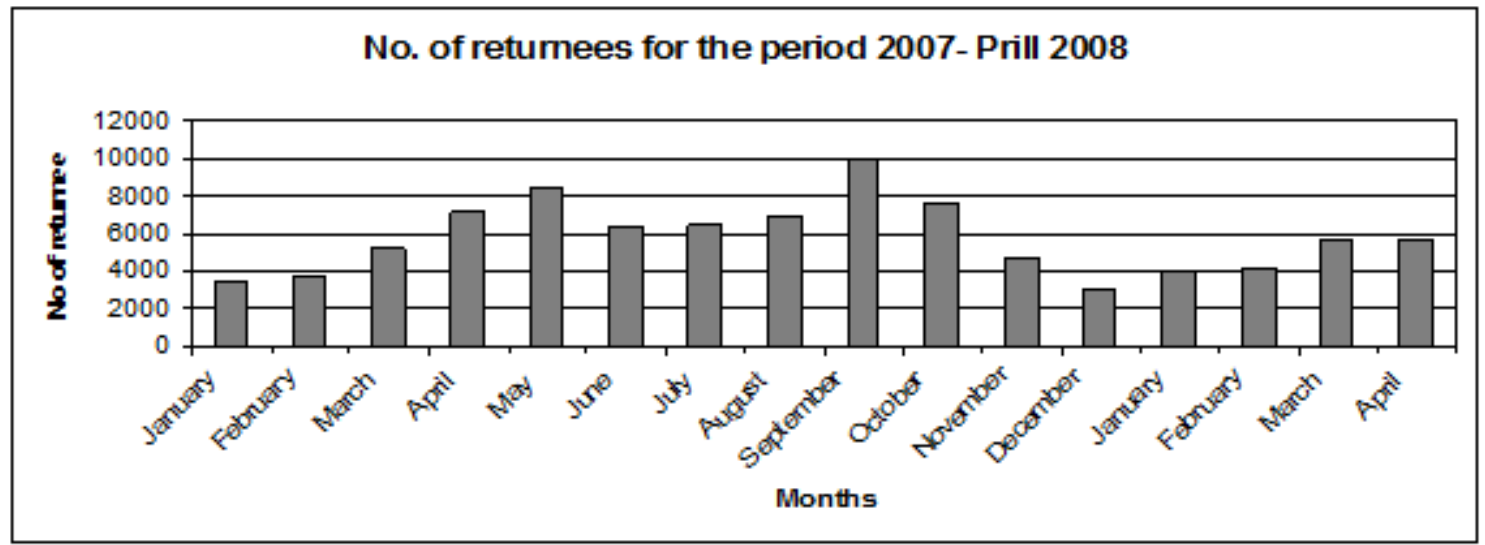

Figure 2. Number of returnees for period 2007-2008. Source: IOM, Tirana.

Table 1 illustrates the absence of decline of returnees flux within the last two years. The first trimester, marks an increase of returnees, in the meantime in April 2008 one might as well notice a decline of returnees numbers when compared with April 2007 figures. Such a development could have happened occasionally, or due to a decrease of the flux of the returnees, the second option is less likely as the following data will explain the situation for the next months. 
Table 1

Flux of Returnees

\begin{tabular}{|c|c|c|c|c|c|c|c|}
\hline Year & Jan. & Feb. & Mar. & Apr. & Total & Monthly average & Daily average \\
\hline 2007 & 3,429 & 3,677 & 5,193 & 7,243 & 19,542 & $4,885.5$ & 162.85 \\
\hline 2008 & 4,015 & 4,198 & 5,671 & 5,720 & 19,604 & 4,901 & 163.37 \\
\hline
\end{tabular}

In addition, TIMS provides data for the returnees according to their gender where male predominates (95.4\%), this phenomenon is related not only to the structure of the undocumented migrants attempting to pass the Greek border, but also due to the fact that female tend by nature to avoid the irregular and illegal cross of the border. We think that the irregular cross of the border for female happens mainly as a result of the human traffic or due to the problems faced with the provision of the regular documentation for family unification. It is noted that the major part of the returnees are male above 18 years old. High level of returned minors is marked as well with a specific weight of $(15.5 \%+0.9 \%)$. This reality must be taken seriously in consideration by the government of Albania. The society must reflect on this phenomenon that may compound a social concern for Albania. It should be emphasized also that the structure of minor returnees within the gender category represents small changes if one compares female migrants $(3.7 \% / 0.9 \%=4.11$ times higher than the adult females) with male migrants $(79.9 \% / 15.5 \%=5.16$ times higher than the adult males) (see Figure 3).

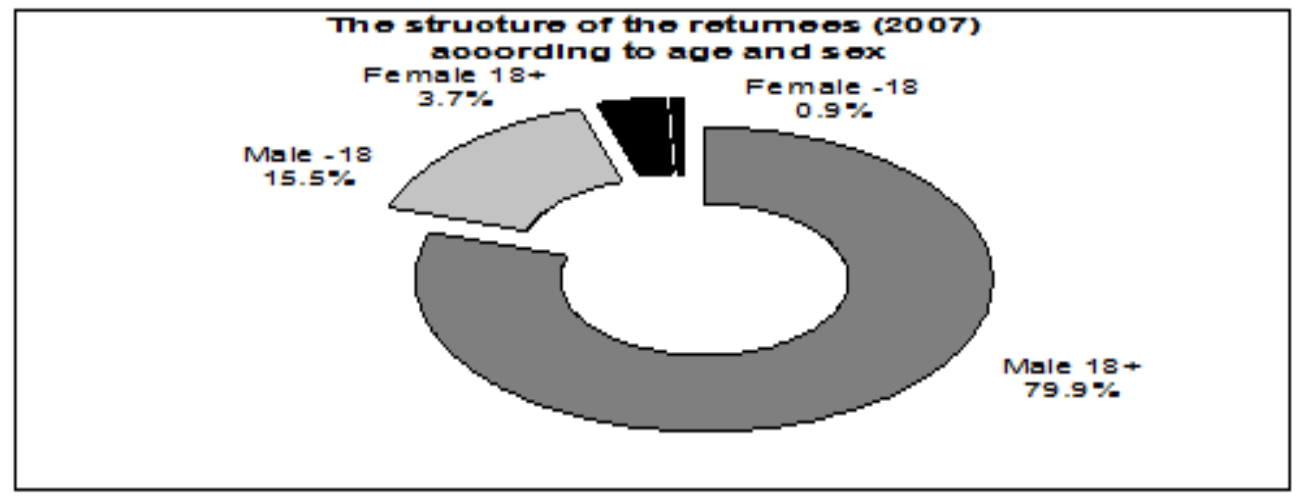

Figure 3. The structure of the returnees. Source: IOM, Tirana.

The available data enables the authors to conclude the following:

Fifteen out of sixty-two countries represent $99.44 \%$ of the return cases. Therefore, the rest of 47countries count only for $0.56 \%$ of the return phenomenon. A considerable number of returnees have been classified under the category of "unknown" respectively $13.94 \%$ and another $1.00 \%$ under "Albania". Such an equivocal classification explicates the lack of qualification and proper training of police officers handling the readmission system at the BC. They have mistakenly recorded the data regarding $14.94 \%$ of the returnees which makes it impossible for authors to elaborate on this specific data. The other table provides for $90 \%$ of the returnees to have been returned from Greece. At the same time, the same table provides for $91.34 \%$ of returnees to have been qualified as returned from “Greece, Unknown, Albania”. Therefore, the assumption may be that main obstacles and challenges faced by police officers have occurred at the BC with Greece.

The majority of the returned migrants, as it results from the TIMS, are classified as males, of young age and with a low education level (up to eight years old). 
The returned migrants from Greece have a lower education level and female predominates when compared to migrants returned from the more developed European.

The duration for the illegal migrants is found to be shorter for females rather than males. In addition, migration of Albanian nationals to the UK tends to last longer in comparison to migration to Greece. When approaching the return migration with the purpose of comparison the deportation process from Greece and from the UK the outcomes is that deportation process takes longer in the UK. Returnees from the UK have been classified as subjects of criminal conviction prior to deportation and have been captured often at their residences or while working. Adopting Clayton's (2008) interpretation of the Immigration and Asylum Law in the UK, the deportation process in the UK must encounter certain steps that require the necessary time for a deportation process to take place in compliance with the UK legislation. On the contrary the deportations from Greece take little timing as the undocumented migrants are often captured at the Greek border or in the Greek territory and deported immediately.

With regard to professions of the returnees those may be various ones. Nevertheless the common feature of returned migration is that the predominant professions relate to agriculture, construction even service workers like erector, hydraulic, etc.. One might even acknowledge that migrants continue to perform the same work (or continue to use the same professional skills) therefore a match of skills with the ones used in Albania.

\section{Migrant's Perceptions With Regard to Their Migration Journey}

When analysing the interviewer's response with regard to their reasons for migrating one may easily reflect on Castaldo, Litchfield, and Reilly's (2007) argument that in spite of positive and steady economic developments, lack of job opportunities in Albania remains highly elaborated by returned migrants as well with a light trend to qualify poverty as the main reason for migrating purposes. Albanian female returned migrants prove an exception as their migration reasons consist of family unification (therefore uncovering another interesting component of gender and migration relation). More than half of migrants send money to their families, or relatives in Albania. The transfer of their remittances is mostly completed by males, middle or old age, migrants from the U.K. and long term migrants. Sending money "through relatives, or friends" or "through banking system" it is the common practise of use of social kinships. Nearly all interviewees are willing to migrate again and at the same time just about all the interviewees require assistance in order to not migrate again. There is not an inconsistency in this fact because migrants are fully aware of the very low level of assistance that they will receive.

The majority of migrants require an intermediation in order to find a job, financial assistance and regular visa. Female migrants tend to require more financial assistance, visa assistance for family unification, while male migrants require intermediation for finding a job and for professional training.

\section{Conclusion}

The paper has attempted to unfold certain socio-economic characteristics of returned Albanian undocumented migrants. It is important to recognise that this paper supports the assumption that irregular migration continues to function as a phenomenon in Albania and in this context migration phenomenon will be a response to economic developments rather than a driver of economic prosperity.

Authors wish to conclude with a number of recommendations from a policy point of view as well as 
emphasize interesting elements for future research as migration and development seem to be quite interlinked with one another.

In the context of development the government of Albania ought to consider the multi-disciplinary approach with regard to migration policies as well as prioritize efficient implementation of those policies with regard to illegal migration. It is necessary to conclude bilateral agreements in particular with countries where undocumented Albanian migrants reside and contribute with the aim to regulate seasonal or circulated migration.

The National Employment Service alongside with Regional Employment Offices must align the registration of migrants with accurate data aiming so the compliance with its mission. REO ought to create and develop a better cooperation with the structure of the border police in order to complete the registration of migrants at the border and through their voluntary will. A registration form may be compiled for this purpose.

The central, legislative and executive power, alongside the local government have to play a more active and powerful role regarding the compilation and application of the more qualitative policies with regard to legal employment and the fight grey market employment. Ongoing monitoring should be applied upon businesses with regard to compliance with standards of employment, wages and daily working hours.

REO and VTC need to ameliorate their role for better dissemination of the information with regard to trainings and employment opportunities provided. REO and perhaps VTC may consider the establishment of boards with informative resources in every PBC aiming to assist returned migrants.

Various local NGO must increase their involvement in distributing information for returned migrants with regard to employment and vocational educational training.

With regard to Greek Border Authorities in order to comply with readmission agreement as well as human rights standards well defined within the European Convention of Human Rights and other international covenants ought to arrange for better deportation equipments shortening in some cases the return process for Albanian undocumented migrants.

\section{References}

Albanian Institute for International Studies. (2005). Albanian brain drain: Turning the tide. Tirana

Apostolatou, K. (2006). Country report Immigrant and immigration policy-making: A review of the literature of the Greek case. IMISCOE working paper.

Black, R., Jones, L., Pantiru, M., Wheeler, R., Skeldon, R., \& Vathi, Z. (2007). Understanding migration as a driver of poverty reduction in Europe and central Asia. Sussex Center for Migration Research, Institute for Development Studies, Free University of Brussels, working paper C-9.

Bonifazi, C. (2007). L'Immigrazione straniera in Italia. Bologna: il Mulino.

Castaldo, A., Litchfield, J., \& Reilly, B. (2007). Who is likely to migrate from Albania? Eastern European Economics, 45(5), 69-94.

Center for Economic and Social Studies (CESS). (2003). The encouragement of social-economic development in relation to the growth of the role of the remittances. Final draft, Research Report commissioned by UNDP and Soros Foundation, August 2003.

Civici, A., Gedeshi, I., \& Shehi, D. (1999). Migration, agriculture and rural development in Albania, Bulgaria and FYR of Macedonia: The Case of Albania. the ACE Phare Programme, No. P-96-6070R.

Clayton, G. (2008). Textbook on immigration and asylum law (3rd ed.). Oxford University Press Great Clarendon Street, Oxford OX2 6DP.

Dalipaj, M. (2005). Albanian migration to the UK: A hidden migration? Brighton: University of Sussex, MPhil thesis in Migration Studies. 
De Zwager, N., Gedeshi, I., Germenji, E., \& Nikas, Ch. (2005). Competing for remittances. IOM.

Germenji, E. (2005). Does human capital matter? Integration of Albanian immigrants in the Greek labour market, paper presented at the Marie Curie Conference on Multi-Level Governance of Immigration Flows, Athens, Greece, March 30-April 3, 2005.

Government of Albania. (2004). The national strategy for migration. approved by CMD No. 760, date 19.11.2004.

Government of Albania. (2005). The national plan of actions for migration. approved by CMD No. 296, date 06.05.2005.

INSTAT. (2004). Migration in Albania. 2001 REPOBA. Tirana: Instituti i Statistikës.

IOM. (2006). Return and readmission. The case of Albania. Tirana: International Organization for Migration.

Kilic T., Carletto G., Davis B., \& Zezza, A. "Investing Back Home: Return Migration and Business Ownership in Albania ESA working paper No. 07-08, July 2007.

King, R., \& Vullnetari, J. (2003). Migration and development in Albania. Brighton: University of Sussex, Development Research Centre on Migration, Globalization and Poverty, working paper C5.

Meksi, E. (1996). Immigration, demographic trends and labour market: The case of Albania. paper presented at Mediterranean Conference on Population, Migration and Development, Palma de Mallorca, October 15-17, Council of Europe.

Memaj F. (2004, October) Albania: Vortices of imbalance, Higher Education in Europe, XXIX(3).

Memaj, F. (2008). Study on the socio-economic profile of emigrants returning in Albania. IOM, Tirana, 2008.

Memaj, F., \& Theodhori, Q. (1996). Urbanization or ruralisation of industrial towns. Review “Studimet e Popullsisë” Nr. 5, Tirana.

Memaj. F. (1996). Migration, problems and socio economic impact. Review, “Studime të Popullsisë”, Nr. 3, Tirana.

Opie, A. (1992). Research, appropriation of the "other” and empowerment. Feminist Review, 40(Spring), 52-69.

The Albania Government, IOM and European Union. (2005). De bruycker, P. Obtaining VISA from EU: The case of Albania. In Is the conclusion of the readmission agreement a necessary but insufficient condition? Tirana financed under the CARDS 2001 programme of EC for Albania.

UNDP. (2006). From brain drain to brain gain, mobilizing the Albanian Diaspora. Policy Paper for the Albanian Government. 